\title{
Psychological Reactions among Staffs of a Tertiary Eye Hospital in Eastern Nepal during COVID-19 Pandemic
}

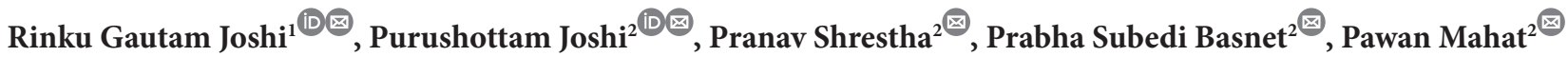 \\ ${ }^{1}$ BP Koirala Institute of Health Sciences, Dharan, Nepal \\ ${ }^{2}$ Mechi Eye Hospital, Birtamode, Jhapa, Nepal
}

\begin{abstract}
Introduction: Eye examination and different procedures performed in close contact with eye and face, put medical and non medical staff of an eye hospital at higher risk for COVID-19. This causes increased psychological burden. The objective of this study was to find out depression, anxiety, stress and insomnia among Mechi Eye Hospital staff.

Materials and methods: A web based cross-sectional study among Mechi Eye Hospital staff was done from 1st to 20th July 2020. Insomnia Severity Scale and DASS-21 were used.

Results: Out of 220, $190(86.6 \%)$ participated, $63.2 \%$ were female and $61.05 \%$ were medical staff with an overall mean age of $31.1 \pm 8.4$ years. Overall prevalence of anxiety, depression, insomnia and stress were $20.5 \%, 18.9 \%, 16.3 \%$ and $12.6 \%$ respectively and those were common in female with $63.9 \%$ ( $p$ value $<0.02$ ), 64.1\% (p value 0.5 ), 58.4\% ( $\mathrm{p}$ value 0.2 ) and $100 \%$ ( $\mathrm{p}$ value $<0.01$ ) respectively. Depression, anxiety and insomnia were common in the age group 30-39 years $(50 \%$, p value $<0.02), 20-29$ years ( $56.4 \%$, p value 0.1$)$ and $20-29$ years $(70.9 \%$, p value 0.8$)$ respectively. Stress was common in 20-29 years and 30-39 years, $45.8 \%$ each ( $\mathrm{p}$ value $<0.03$ ). Depression ( $75 \%$, p value 0.2 ), anxiety $(71.7 \%$, p value 0.9 ) and stress $(70.8 \%$, p value 1.0$)$ were common in medical staff. Insomnia was present in medical staff only (p value $<0.01$ ).

Conclusion: Mechi Eye Hospital staff had greater prevalence of psychological reaction than the national baseline during the pandemic which was more common in female, younger age and medical staff.

Key words: Anxiety, COVID-19 pandemic, Depression, Eastern Nepal, Eye care service providers, Insomnia, Stress.
\end{abstract}

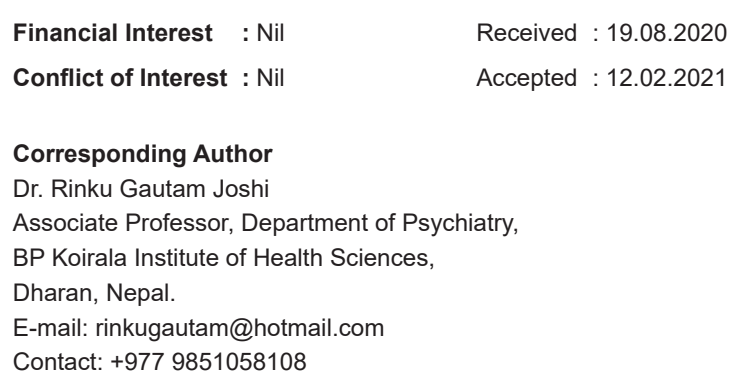

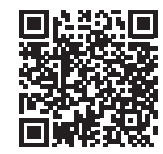

Access this article online

Website: www.nepjol.info/index.php/NEPJOPH

DOI: https://doi.org/10.3126/nepjoph.v13i2.32887

Copyright $\odot 2021$ Nepal Ophthalmic Society ISSN: 2072-6805, E-ISSN: 2091-0320

This work is licensed under a Creative Commons

Attribution-NonCommercial-NoDerivatives 4.0 International License (CC BY-NC-ND). 


\section{INTRODUCTION}

Nepal recorded its first case of COVID-19 on $5^{\text {th }}$ January 2020 (Bastola et al., 2020), WHO declared this condition a global pandemic on $11^{\text {th }}$ March 2020 (WHO, 2020b). Nepal Government declared a nationwide lockdown except for essential services from $24^{\text {th }}$ March 2020 to $21^{\text {st }}$ July 2020 . In the meantime, from $15^{\text {th }}$ June, all medical services and hospitals were allowed to open.

DrLi Wenliang, an ophthalmologist from Wuhan, China first brought into notice COVID-19 (Green, 2020). He contracted COVID-19 while managing his asymptomatic glaucoma patient and succumbed to COVID-19 on $7^{\text {th }}$ February 2020. Mechi Eye Hospital (MEH) is a charitable eye hospital situated in Jhapa District of Mechi Zone providing service to the eastern Nepal. In this pandemic, during the lockdown, only the emergent and urgent cases were seen till $15^{\text {th }}$ June 2020, then after, the hospital was opened for all the cases as advised by the Government of Nepal. Screening of the patients coming to the hospital was done as per guidelines provided by Nepal Ophthalmic Society (NOS), and no definitive tests for COVID-19 were done (NOS, 2020). Each and every patient was treated as a COVID-19 suspect. In eye hospitals, eye examination and procedures are performed in close contact with the eyes and face of the patients, putting the eye care service providers like ophthalmologists, optometrists, ophthalmic assistants, eye health workers and non-medical support staff at an increased risk for
COVID-19 transmission. Aerosolized particles on the equipment contributed to a high risk of transmission. (Van Doremalen et al., 2020). In addition to this, within $\mathrm{MEH}$ premises, there is a Government quarantine centre for the COVID-19 suspected persons.

Early evidence and studies show that a substantial proportion of health care professionals (HCPs) performing their duty in this pandemic experience mood and sleep disturbances. In the past, during severe acute respiratory syndrome (SARS) outbreak as well, studies showed adverse psychological reactions among the HCPs and the common psychological reactions were sleep disorder, stress, anxiety and depression. (Bai Y et al, 2004) Globally in this pandemic, the prevalence of anxiety, depression, insomnia and stress in general population were $21.6 \%, 20.1 \%, 18.2 \%$ and $35 \%$ respectively whereas in $\mathrm{HCP}$ it were $13 \%$ to $40 \%, 5.3$ to $48 \%, 18 \%$ to $60 \%$ and $2.2 \%$ to $37 \%$ respectively. (Tan et al., 2020; Luo et al., 2020; Shechter et al., 2020; Tu et al., 2020; Huang and Zhao, 2020; González-Sanguino et al., 2020; Chew et al., 2020; Liu et al., 2020; Kang et al., 2020; Zhou et al., 2020; Zhang et al., 2020a; Liang et al., 2020; Gambin et al., 2020; Pappa et al., 2020; Albert, 2015; Hatcher et al., 2016; Lai et al., 2020; Zhang et al., 2020b; Lu et al., 2020). These are the studies done on the frontline HCP, directly involved with COVID-19 patients, but the pandemic also adversely affects the mental health of non-frontline HCP such as those in eye care delivery. 
For the MEH staff, factors like no definitive treatment or vaccine for COVID-19, unknown status of the patient, asymptomatic transmission, quarantine centre within the hospital premises and the eye care profession itself might add psychological burden. This study aims to provide a prevalence of stress, anxiety, depression and sleep disorder among the staff of MEH.

\section{MATERIAL AND METHODS}

This is a web based cross-sectional study among the MEH staff and responses were collected from $1^{\text {st }}$ to $20^{\text {th }}$ July 2020. The study was approved by the MEH board and adhered to the tenets of the declaration of Helsinki. The semi structured proforma, DASS-21 (Depression, Anxiety and Stress Scale) and ISI (Insomnia Severity Scale) were uploaded through Google Forms. The link was shared by email and instant messaging apps to all. The first section included the introduction of the study and the consent to participate. Only after the participant gave consent, they could access other sections. The second section was a semi structured proforma including demographic variables like age, sex, marital status, residence, position and department. The third section was the DASS21 questionnaire and the fourth section was the ISI questionnaire. The confidentiality of each participant was assured and they could opt out at any time. Also, the survey was kept anonymous.

MEH staff included medical HCP (ophthalmologists, staff nurses, optometrists, ophthalmic assistants, eye health workers) and non-medical or administrative HCP (pharmacists, opticians, technicians, administrators, waste management staff, security guards and maintenance staff).

DASS-21: A shorter 21 -item version DASS is the modification of the original 42-item DASS of Lovibond (Antony et al., 1998) in which the participants themselves report the frequency and severity of experiencing negative emotions over the previous week, rated on a series of 4-point scales $(0-$ not applicable to me to 3 -applied to me very much or most of the time). The interpretation is made based on the total score obtained as follows: for depression: Score less than 10 is considered normal, while score of 10 - 13 is considered mild, $14-20$ is moderate, $21-27$ is severe and more than 27 is extremely severe; anxiety: Score less than 8 is considered normal, while score of $8-9$ is considered mild, $10-14$ is moderate, $15-19$ is severe and more than 19 is extremely severe and stress: Score less than 15 is considered no stress, while score of $15-18$ is considered mild, $19-25$ is moderate, $26-33$ is severe and more than 33 is extremely severe.

ISI: The nature, severity, and impact of insomnia was assessed using a 7- item self reported questionnaire in the ISI (Morin et al., 2011). Severity of sleep onset, sleep dissatisfaction, sleep maintenance and early morning awakening problems, noticeability of sleep problems by others, distress caused by sleep difficulties and interference with daytime functioning are the 
dimensions evaluated in the usual recall period of 'last month'. Total score yielded ranges from 0 to 28 using a 5 point Likert scale, with score of 0-7 interpreted as absence of insomnia, 8-14 as subthreshold insomnia, 15-21 as moderate insomnia and 22-28 as severe insomnia.

Data were transferred to Microsoft Excel and were analyzed using SPSS version 23 and appropriate tests applied. All tests were performed at 95\% Confidence Interval (CI) and a p-value of $<0.05$ was considered statistically significant.

\section{RESULTS}

Total 190 MEH staff out of total 220 staff constituting $86.6 \%$ participated in the study. Among them $116(61.05 \%)$ were medical staff whereas $74(38.95 \%)$ were non-medical administrative staff. There was female preponderance in the overall staff $(120$, $63.2 \%)$ and medical staff 83 (71.6\%), but, gender distribution was equal $(37,50 \%)$ in administrative staff. The mean age group of the participants was $31.11 \pm 8.41$ years. Table 1 shows the characteristics of the participants.

Table 1: Characteristics of the participants.

\begin{tabular}{|c|c|c|c|c|}
\hline Char & acteristics & Total & $\begin{array}{l}\text { Medical health } \\
\text { care personnel }\end{array}$ & $\begin{array}{l}\text { Administrative } \\
\text { health care } \\
\text { personnel }\end{array}$ \\
\hline & Male & $70(36.8 \%)$ & $33(28.4 \%)$ & $37(50 \%)$ \\
\hline Gender & Female & $120(63.2 \%)$ & $83(71.6 \%)$ & $37(50 \%)$ \\
\hline & Range & $20-59$ & $20-45$ & $20-59$ \\
\hline & Mean \pm SD & $31.11 \pm 8.41$ & $28.45 \pm 5.03$ & $35.30 \pm 10.70$ \\
\hline & Median & 29 & 28 & 34.5 \\
\hline & Mode & 28 & 26 & 28 \\
\hline Age in years & $20-29$ & $101(53.2 \%)$ & $73(72.2 \%)$ & $28(27.8 \%)$ \\
\hline & 30-39 & $63(33.1 \%)$ & $40(63.5 \%)$ & $23(36.5 \%)$ \\
\hline & $40-49$ & $15(7.9 \%)$ & $3(20 \%)$ & $12(80 \%)$ \\
\hline & $50-59$ & $11(5.8 \%)$ & 0 & $11(100 \%)$ \\
\hline & Unmarried & $73(38.4 \%)$ & $51(43.9 \%)$ & $22(29.7 \%)$ \\
\hline Mritat Crt & Married & $114(60 \%)$ & $65(56.1 \%)$ & $49(66.3 \%)$ \\
\hline Mrantal status & Widow & $2(1.1 \%)$ & & $2(2.7 \%)$ \\
\hline & Divorce & $1(0.5 \%)$ & & $1(1.3 \%)$ \\
\hline & Hospital Quarter & $13(6.8 \%)$ & $13(100 \%)$ & 0 \\
\hline Accommodation & Rented flat & $39(20.5 \%)$ & $30(76.9 \%)$ & $9(23.1 \%)$ \\
\hline & Home & $138(72.6 \%)$ & $73(52.8 \%)$ & $65(47.2 \%)$ \\
\hline & Alone & $35(18.4 \%)$ & $28(80 \%)$ & $7(20 \%)$ \\
\hline Living & \begin{tabular}{|l} 
Family \\
\end{tabular} & $155(81.6 \%)$ & $88(56.7 \%)$ & $67(43.3 \%)$ \\
\hline
\end{tabular}




\begin{tabular}{|l|l|c|c|c|}
\hline \multirow{5}{*}{} & Ophthalmologist & & $14(12.1 \%)$ & \\
\cline { 2 - 4 } & Optometrist & & $10(8.6 \%)$ & \\
\cline { 2 - 5 } & Ophthalmic Assistant & & $33(28.4 \%)$ & \\
\cline { 2 - 5 } Occupation & Staff Nurse & & $5(4.4 \%)$ & \\
\cline { 2 - 5 } & Eye Health Worker & & $54(46.5 \%)$ & \\
\cline { 2 - 5 } & Administration & & & $3(25.7 \%)$ \\
\cline { 2 - 5 } & Pharmacy & & & $29(39.1 \%)$ \\
\cline { 2 - 5 } & Optical & & & $16(21.6 \%)$ \\
\cline { 2 - 5 } & Waste Management & & & $7(9.4 \%)$ \\
\hline & Security & & \\
\hline
\end{tabular}

The overall prevalence of depression, anxiety, $\quad 8.9 \%)$, mild stress $(16,8.4 \%)$ and subthreshold stress and insomnia were $36(18.9 \%), 39(20.5 \%)$, insomnia $(24,12.6 \%)$ were the most common as $24(12.6 \%)$ and $31(16.3 \%)$ respectively. Mild shown in Table 2.

depression $(19,10 \%)$, moderate anxiety $(17$,

Table 2: Participants score on Depression, Anxiety, Stress and Insomnia.

\begin{tabular}{|c|c|c|c|c|c|c|c|}
\hline \multirow[b]{2}{*}{ Diagnosis } & \multirow[b]{2}{*}{$\begin{array}{l}\text { Total } \\
\text { (190) }\end{array}$} & \multirow{2}{*}{$\begin{array}{c}\text { Mean } \\
\text { Scores } \\
\text { Overall } \\
\text { Cases }\end{array}$} & \multirow{2}{*}{$\begin{array}{l}\text { Mean } \\
\text { Score in } \\
\text { Positive } \\
\text { Cases }\end{array}$} & \multicolumn{4}{|c|}{ DASS21 scale and grading } \\
\hline & & & & Mild & Moderate & Severe & $\begin{array}{c}\text { Extremely } \\
\text { Severe }\end{array}$ \\
\hline \multirow[b]{2}{*}{ Depression $\geq 10$} & \multirow[b]{2}{*}{$\begin{array}{c}36 \\
(18.9 \%)\end{array}$} & \multirow[b]{2}{*}{$4.42 \pm 6.21$} & \multirow[b]{2}{*}{$14.89 \pm 6.70$} & Score 10-13 & $14-20$ & $21-27$ & $28+$ \\
\hline & & & & $\begin{array}{c}19 \\
(10 \%)\end{array}$ & $\begin{array}{c}12 \\
(6.3 \%)\end{array}$ & $\begin{array}{c}3 \\
(1.5 \%)\end{array}$ & $\begin{array}{c}2 \\
(1.1 \%)\end{array}$ \\
\hline \multirow[b]{2}{*}{ Anxiety $\geq 8$} & \multirow[b]{2}{*}{$\begin{array}{c}39 \\
(20.5 \%)\end{array}$} & \multirow[b]{2}{*}{$4.02 \pm 5.55$} & \multirow[b]{2}{*}{$12.67 \pm 6.30$} & Score $8-9$ & $10-14$ & $15-19$ & $20+$ \\
\hline & & & & $\begin{array}{c}13 \\
(6.8 \%)\end{array}$ & $\begin{array}{c}17 \\
(8.9 \%)\end{array}$ & $\begin{array}{c}5 \\
(2.6 \%)\end{array}$ & $\begin{array}{c}4 \\
(2.2 \%)\end{array}$ \\
\hline \multirow[b]{2}{*}{ Stress $\geq 15$} & \multirow[b]{2}{*}{$\begin{array}{c}24 \\
(12.6 \%)\end{array}$} & \multirow[b]{2}{*}{$5.81 \pm 6.57$} & \multirow[b]{2}{*}{$19.33 \pm 5.86$} & Score $15-18$ & $19-25$ & $26-33$ & $34+$ \\
\hline & & & & $\begin{array}{c}16 \\
(8.4 \%)\end{array}$ & $\begin{array}{c}5 \\
(2.6 \%)\end{array}$ & $\begin{array}{c}2 \\
(1.1 \%)\end{array}$ & $\begin{array}{c}1 \\
(0.5 \%)\end{array}$ \\
\hline \multirow{4}{*}{$\begin{array}{l}\text { Insomnia } \\
\text { ISI score } \geq 8\end{array}$} & \multirow{4}{*}{$\begin{array}{c}31 \\
(16.3 \%)\end{array}$} & \multirow{4}{*}{$3.21 \pm 4.14$} & \multirow{4}{*}{$10.97 \pm 4.61$} & \multicolumn{4}{|c|}{ ISI scores and grading } \\
\hline & & & & $\begin{array}{c}\text { Subthresholc } \\
\text { Insomnia }\end{array}$ & $\begin{array}{l}\text { Clinic } \\
\text { Insom }\end{array}$ & & $\begin{array}{l}\text { Clinical } \\
\text { Insomnia }\end{array}$ \\
\hline & & & & Score 8-14 & $\begin{array}{r}\text { Moder } \\
15-2\end{array}$ & & $\begin{array}{l}\text { Severe } \\
22-28\end{array}$ \\
\hline & & & & $\begin{array}{c}24 \\
(12.6 \%)\end{array}$ & $\begin{array}{r}5 \\
(2.6 \% \\
\end{array}$ & & $\begin{array}{c}2 \\
(1.1 \%)\end{array}$ \\
\hline
\end{tabular}


The prevalence of all these conditions were high among females, with only female staff found to be suffering from insomnia, while relation between gender and depression using MannWhitney U test was found to be statistically significant. The DASS-21 mean score was more in male than female as shown in Table 3.

Depression, anxiety, and insomnia were most common in the age group $30-39$ years $(18$, $50 \%), 20-29$ years $(22,56.4 \%)$ and $20-29$ years $(22,70.9 \%)$ respectively. Stress was common in the age group $20-29$ years and 30 - 39years, 11(45.8\%) in each. Using the nonparametric one way ANOVA (Kruskal-Wallis $\mathrm{H}$ test) the relation between age and depression; and age and stress was statistically significant as shown in Table 4.

Table 3: Psychological symptoms and gender.

\begin{tabular}{|l|c|c|c|c|c|c|}
\hline \multirow{2}{*}{ Diagnosis } & \multirow{2}{*}{ Total } & \multicolumn{4}{|c|}{ Gender } & P value \\
\cline { 3 - 7 } & Male & Mean Score & Female & Mean Score & \\
\hline Depression $\geq 10$ & 36 & $\begin{array}{c}13 \\
(36.1 \%)\end{array}$ & $18.92 \pm 9$ & $\begin{array}{c}23 \\
(63.9 \%)\end{array}$ & $12.61 \pm 3.49$ & 0.010 \\
\hline Anxiety $\geq 8$ & 39 & $\begin{array}{c}14 \\
(35.9 \%)\end{array}$ & $14.29 \pm 9.04$ & $\begin{array}{c}25 \\
(64.1 \%)\end{array}$ & $11.76 \pm 4.01$ & 0.539 \\
\hline Stress $\geq 15$ & 24 & $\begin{array}{c}10 \\
(41.6 \%)\end{array}$ & $21.60 \pm 8.40$ & $\begin{array}{c}14 \\
(58.4 \%)\end{array}$ & $17.71 \pm 2.33$ & 0.286 \\
\hline Insomnia & 31 & 0 & & $\begin{array}{c}31 \\
(100 \%)\end{array}$ & $10.97 \pm 4.61$ & $<0.01$ \\
\hline ISI score $\geq 8$ & & & & & & \\
\hline
\end{tabular}

Table 4: Age and psychological symptoms.

\begin{tabular}{|c|c|c|c|c|c|c|c|c|c|c|}
\hline \multirow[b]{2}{*}{ Diagnosis } & \multirow[b]{2}{*}{ Total } & \multicolumn{8}{|c|}{ Age Group } & \multirow[b]{2}{*}{ P value } \\
\hline & & $\begin{array}{l}20-29 \\
\text { years }\end{array}$ & $\begin{array}{l}\text { Mean } \\
\text { Score }\end{array}$ & $\begin{array}{l}30-39 \\
\text { years }\end{array}$ & $\begin{array}{l}\text { Mean } \\
\text { Score }\end{array}$ & \begin{tabular}{|l|}
$40-49$ \\
years
\end{tabular} & \begin{tabular}{|l|} 
Mean \\
Score
\end{tabular} & \begin{tabular}{|l|}
$50-59$ \\
years
\end{tabular} & $\begin{array}{l}\text { Mean } \\
\text { Score }\end{array}$ & \\
\hline Depression $\geq 10$ & 36 & $\begin{array}{c}16 \\
(44.4 \%)\end{array}$ & $12.25 \pm 4.12$ & $\begin{array}{c}18 \\
(50 \%) \\
\end{array}$ & $16.78 \pm 8.06$ & 0 & 0 & $\begin{array}{c}2 \\
(5.6 \%) \\
\end{array}$ & $\begin{array}{l}19 \pm \\
1.41 \\
\end{array}$ & 0.014 \\
\hline Anxiety $\geq 8$ & 39 & $\begin{array}{c}22 \\
(56.4 \%) \\
\end{array}$ & $11.09 \pm 3.58$ & $\begin{array}{c}16 \\
(41 \%) \\
\end{array}$ & $14.50 \pm 8.56$ & 0 & 0 & $\begin{array}{c}1 \\
(2.6 \%) \\
\end{array}$ & 18 & 0.18 \\
\hline Stress $\geq 15$ & 24 & \begin{tabular}{c|c|}
11 \\
$(45.8 \%)$ \\
\end{tabular} & $16.91 \pm 1.37$ & $\begin{array}{c}11 \\
(45.8 \%) \\
\end{array}$ & $22.36 \pm 7.63$ & 0 & 0 & $\begin{array}{c}2 \\
(8.4 \%) \\
\end{array}$ & 16 & 0.025 \\
\hline $\begin{array}{l}\text { Insomnia } \\
\text { ISI score } \geq 8\end{array}$ & 31 & $\begin{array}{c}22 \\
(70.9 \%) \\
\end{array}$ & $11.50 \pm 5.21$ & $\begin{array}{c}8 \\
(25.9 \%) \\
\end{array}$ & $9.63 \pm 2.61$ & $\begin{array}{c}1 \\
(3.2 \%) \\
\end{array}$ & 10 & 0 & 0 & 0.841 \\
\hline
\end{tabular}


Table 5: Working area and psychological symptoms.

\begin{tabular}{|c|c|c|c|c|c|c|}
\hline \multirow[b]{2}{*}{ Diagnosis } & \multirow[b]{2}{*}{ Total } & \multicolumn{4}{|c|}{ Working area } & \multirow[b]{2}{*}{ P value } \\
\hline & & $\begin{array}{l}\text { Medical } \\
\text { HCP }\end{array}$ & Mean score & $\begin{array}{c}\text { Administrative } \\
\text { HCP }\end{array}$ & $\begin{array}{l}\text { Mean } \\
\text { score }\end{array}$ & \\
\hline Depression $\geq 10$ & 36 & $\begin{array}{c}27 \\
(75 \%)\end{array}$ & $13.70 \pm 4.80$ & $\begin{array}{c}9 \\
(25 \%)\end{array}$ & $\begin{array}{c}18.44 \pm \\
10.13\end{array}$ & 0.215 \\
\hline Anxiety $\geq 8$ & 39 & $\begin{array}{c}28 \\
(71.7 \%)\end{array}$ & $12 \pm 3.92$ & $\begin{array}{c}11 \\
(28.3 \%)\end{array}$ & $\begin{array}{c}14.36 \pm \\
10.23\end{array}$ & 0.974 \\
\hline Stress $\geq 15$ & 24 & $\begin{array}{c}17 \\
(70.8 \%)\end{array}$ & $18.35 \pm 2.93$ & $\begin{array}{c}7 \\
(29.2 \%)\end{array}$ & $21.71 \pm 9.96$ & 1.000 \\
\hline $\begin{array}{l}\text { Insomnia } \\
\text { ISI score } \geq 8\end{array}$ & 31 & $\begin{array}{c}31 \\
(100 \%)\end{array}$ & $10.97 \pm 4.61$ & 0 & & $<0.01$ \\
\hline
\end{tabular}

All the psychological impacts were more Whitney U test) as shown in Table 5. common in medical personnel. Depression, anxiety and stress were 27 (75\%), 28 (71.7\%) and $17(70.8 \%)$ respectively. Insomnia was present only in the medical personnel. Relations between depression, stress and anxiety within the working area was not significant (Mann-

The psychological symptoms were more common in participants living with family than living alone, but it was not statistically significant (Mann-Whitney U test) as shown in Table 6.

Table 6: Living condition and psychological symptoms.

\begin{tabular}{|c|c|c|c|c|c|c|}
\hline \multirow{2}{*}{ Diagnosis } & \multirow{2}{*}{ Total } & \multicolumn{4}{|c|}{ Living condition } & \multirow{2}{*}{ P value } \\
\hline & & Alone & Mean score & Family & Mean Score & \\
\hline Depression $\geq 10$ & 36 & $\begin{array}{c}12 \\
(33.3 \%) \\
\end{array}$ & $14.67 \pm 9.51$ & $\begin{array}{c}24 \\
(66.7 \%) \\
\end{array}$ & $15 \pm 5$ & 0.147 \\
\hline Anxiety $\geq 8$ & 39 & $\begin{array}{c}10 \\
(25.6 \%) \\
\end{array}$ & $13.80 \pm 10.17$ & $\begin{array}{c}29 \\
(74.5 \%) \\
\end{array}$ & $12.28 \pm 4.46$ & 0.895 \\
\hline Stress $\geq 15$ & 24 & $\begin{array}{c}5 \\
(20.8 \%) \\
\end{array}$ & $21.60 \pm 11.44$ & $\begin{array}{c}19 \\
(79.2 \%)\end{array}$ & $18.74 \pm 3.6$ & 0.732 \\
\hline $\begin{array}{l}\text { Insomnia } \\
\text { ISI score } \geq 8\end{array}$ & 31 & $\begin{array}{c}8 \\
(25.8 \%) \\
\end{array}$ & $8.75 \pm 1.39$ & $\begin{array}{c}23 \\
(74.2 \%) \\
\end{array}$ & $11.74 \pm 5.10$ & 0.117 \\
\hline
\end{tabular}




\section{DISCUSSION}

The study showed the overall prevalence of depression $18.9 \%$, anxiety $20.5 \%$ and stress $12.6 \%$, where mild, moderate, severe and extremely severe were respectively $10 \%, 6.3 \%$, $1.5 \%$ and $1.1 \%$ for depression; $6.8 \%, 8.9 \%$, $2.6 \%$ and $2.2 \%$ for anxiety; and $8.4 \%, 2.6 \%$, $1.1 \%$ and $0.5 \%$ for stress.

The findings we reported are higher compared to prevalence of depression (4.2\%) and anxiety $(16.1 \%)$ in general population of Nepal (Risal et al., 2016) and by Tan BY et al (2020) where the prevalence of depression $8.9 \%$, anxiety $14.5 \%$ and stress were $6.6 \%$. But prevalence reported by Luo et al(2020) is even higher with depression $28 \%$ and anxiety $33 \%$; and Ari Shechter et al(2020) with depression 48\%, anxiety $33 \%$ and stress 57\%; and Tu et al(2020) with $46 \%$ depression and $40 \%$ anxiety. This may be because these studies were done on the frontline HCPs. But a study done in India among ophthalmologists also showed higher prevalence of depression (32.6\%) where $21.4 \%$ had mild; $6.9 \%$ had moderate and $4.3 \%$ had severe depression.(Khanna et al, 2020) However, our study is similar to general population based study by Huang et al(2020) where overall prevalence of depressive symptoms, anxiety and sleep quality were $20.1 \%, 35.1 \%$, and $18.2 \%$, respectively and by González-Sanguino et $\mathrm{al}(2020)$ where depression was in $18.7 \%$, anxiety in $21.6 \%$ and stress symptoms in $15.8 \%$.

The proportion of severity of symptoms were similar to the study by Chew et al(2020) who found 5.3\% moderate to very-severe depression, $8.7 \%$ for moderate to extremely-severe anxiety, $2.2 \%$ for moderate to extremely-severe stress, Liu et al(2020) found prevalence of anxiety was $12.5 \%$ among healthcare workers, from mild $(10.35 \%)$, moderate $(1.36 \%)$ and severe $(0.78 \%)$. Kang et al(2020) also found similar findings, $36.9 \%$ had subthreshold mental health disturbances, $34.4 \%$ had mild disturbances, $22.4 \%$ had moderate disturbances and $6.2 \%$ had severe disturbances.

In this study, $16.3 \%$ had insomnia. The subthreshold insomnia was present in $12.6 \%$, moderate clinical insomnia $2.6 \%$ and severe clinical insomnia in $1.1 \%$. This is similar to the prevalence of poor sleep quality $(18.4 \%)$ found by Zhou et al(2020) but lower than that found by Tu et al (2020) and Zhang et al (2020a) which were $60 \%$ and $36.1 \%$ respectively.

Liang et al (2020) found that younger persons were experiencing clinically significant psychological symptoms than older persons which is similar to this study and also by Gambin et al (2020).

In this study the psychological reactions were more common in females than males, similar to the study by González-Sanguino et al (2020) and by Sofia Pappa et al (2020). This gender gap had also been previously shown by Albert (2015) and Bener et al (2012).

In this study though the prevalence of psychological symptoms were common among the medical staff compared to the nonmedical 
administrative staff, it was not statistically significant and insomnia was only seen in medical staff.

This is similar to the studies done by Lai et al (2020) who reported HCP were associated with statistically significant higher risk of symptoms of depression, anxiety, distress, and insomnia; Zhang et al (2020b) found higher prevalence of anxiety, depression and insomnia among HCPs, and Lu et al (2020) found that medical staff were likely to feet fear 1.4 times more and two times more likely to suffer anxiety and depression. In our study, a higher mean DASS- 21 score was seen among the nonmedical staff similar to the study by Tan et al. But Tan et al found higher prevalence of anxiety in non-medical HCP (Tan et al., 2020). Jing Qiet al (2020) and Jahrami et al (2020) found that frontline HCP had higher prevalence of sleep disturbances.

Considering the vulnerability of the HCP, WHO has issued 30 points of Mental health and psychosocial consideration during the COVID-19 outbreak on 18th March 2020 among which the 5 points from 7-11 are for HCP (WHO, 2020a).

Even in the hospitals which are not directly involved in the management of COVID-19 patients, like $\mathrm{MEH}$, the reporting information about the psychological reaction of $\mathrm{HCP}$ is essential to plan future prevention strategies to promote mental well-being in this pandemic and beyond.

\section{CONCLUSION}

The staff of MEH had a greater prevalence of psychological reaction than the national baseline at the COVID-19 pandemic. The psychological reaction was more common in females, younger age groups and the medical staff of MEH. The hospital should proactively implement appropriate psychological intervention programmes, to prevent, alleviate or treat increased psychological symptoms of the staff.

\section{Limitation}

This study is a hospital-based study so may not be generalized; and was done during the early mid phase of COVID-19 pandemic, when the scientific knowledge about its transmission and treatment was still evolving, so the results may be overestimated. The socioeconomic status was not assessed, where staff faced salary cutdown. Also, the study was self-selected and done electronically and not by the examiner, so there may be confusion or difficulty in understanding the questions, and chance of selection bias.

Acknowledgement: We would like to acknowledge MEH staff for active participation and MEH management for the support and permission to do this study. 


\section{REFERENCES}

Albert PR (2015). Why is depression more prevalent in women? JPN;40:219. doi: 10.1503/jpn.150205; PMid:26107348

Antony, M. M., Bieling, P. J., Cox, B. J., Enns, M. W., \& Swinson, RP (1998). Psychometric properties of the 42item and 21-item versions of the Depression Anxiety Stress Scales in clinical groups and a community sample. Psychological assessment;10:176. doi: 10.1037/1040-3590.10.2.176

Bai, Y., Lin, C. C., Lin, C. Y., Chen, J. Y., Chue, C. M., \& Chou, P (2004). Survey of stress reactions among health care workers involved with the SARS outbreak. Psychiatric Services;55(9):1055-7. doi: 10.1176/appi.ps.55.9.1055; PMid: 15345768

Bastola, A., Sah, R., Rodriguez-Morales, A.J., Lal, B.K., Jha, R., Ojha, H.C., Shrestha, B., Chu, D.K., Poon, L.L., Costello, A. and Morita, K (2020). The first 2019 novel coronavirus case in Nepal. The Lancet Infectious Diseases;20:279-80. doi: 10.1016/S1473-3099(20)30067-0

Bener A, Ghuloum S and Abou-Saleh MT (2012). Prevalence, symptom patterns and comorbidity of anxiety and depressive disorders in primary care in Qatar. Social psychiatry and psychiatric epidemiology;47:439-46. doi: 10.1007/s00127-011-0349-9; PMid:21293844

Chew, N.W., Lee, G.K., Tan, B.Y., Jing, M., Goh, Y., Ngiam, N.J., Yeo, L.L., Ahmad, A., Khan, F.A., Shanmugam, G.N. and Sharma, AK (2020). A multinational, multicentre study on the psychological outcomes and associated physical symptoms amongst healthcare workers during COVID-19 outbreak. Brain, Behavior, and Immunity;88:559-65. doi: 10.1016/j.bbi.2020.04.049; PMid:32330593

Gambin, M., Sekowski, M., Woźniak-Prus, M., Wnuk, A., Oleksy, T., Cudo, A., Hansen, K., Huflejt-Łukasik, M., Kubicka, K., Lys, AE, Gorgol J (2020). Generalized anxiety and depressive symptoms in various age groups during the COVID-19 lockdown. Specific predictors and differences in symptoms severity. doi: 10.31234/osf.io/42m87

González-Sanguino, C., Ausín, B., ÁngelCastellanos, M., Saiz, J., López-Gómez, A., Ugidos, C., \& Muñoz, M (2020). Mental health consequences during the initial stage of the 2020 Coronavirus pandemic (COVID-19) in Spain. Brain, Behavior, and Immunity. doi: 10.1016/j.bbi.2020.05.040; PMid:32405150

Green A (2020). Li wenliang. The Lancet;395:682. doi: 10.1016/S0140-6736(20)30382-2

Hatcher, S., Coupe, N., Wikiriwhi, K., Durie, M., \& Pillai, A (2016). Te Ira Tangata: a Zelen randomised controlled trial of a culturally informed treatment compared to treatment as usual in Māori who present to hospital after selfharm. Social psychiatry and psychiatric epidemiology;51:885-94. doi: 10.1007/s00127-016-1194-7; PMid:26956679

Huang Y, Zhao N (2020). Generalized anxiety disorder, depressive symptoms and sleep quality during COVID-19 outbreak in China: A web-based cross-sectional survey. Psychiatry Research:112954. doi: 10.1016/j. psychres.2020.112954; PMid:32325383

Jahrami, H., BaHammam, A.S., AlGahtani, H., Ebrahim, A., Faris, M., AlEid, K., Saif, Z., Haji, E., Dhahi, A., Marzooq, H. and Hubail, S (2020). The examination of sleep quality for frontline healthcare workers during the outbreak of COVID-19. Sleep and Breathing:1-9. doi: 10.1007/s11325-020-02135-9; PMid:32592021

Kang, L., Ma, S., Chen, M., Yang, J., Wang, Y., Li, R., Yao, L., Bai, H., Cai, Z., Yang, B.X. and Hu, S (2020). Impact on mental health and perceptions of psychological care among medical and nursing staff in Wuhan during the 2019 novel coronavirus disease outbreak: A cross-sectional study. Brain, Behavior, and Immunity. doi: 10.1016/j. bbi.2020.03.028; PMid:32240764 
Khanna, R. C., Honavar, S. G., Metla,A. L., Bhattacharya,A., \& Maulik, PK(2020). Psychological impact ofCOVID-19 on ophthalmologists-in-training and practising ophthalmologists in India. Indian Journal of Ophthalmology;68(6):994. doi: 10.4103/ijo.IJO_1458_20; PMid:32461412

Lai, J., Ma, S., Wang, Y., Cai, Z., Hu, J., Wei, N., Wu, J., Du, H., Chen, T., Li, R. and Tan, H (2020). Factors associated with mental health outcomes among health care workers exposed to coronavirus disease 2019. JAMA network open 3: e203976-e203976. doi: 10.1001/jamanetworkopen.2020.3976; PMid:32202646

Liang, Y., Chen, M., Zheng, X., \& Liu, J (2020). Screening for Chinese medical staff mental health by SDS and SAS during the outbreak of COVID-19. Journal of psychosomatic research;133:110102. doi: 10.1016/j. jpsychores.2020.110102; PMid:32224344

Liu, C. Y., Yang, Y. Z., Zhang, X. M., Xu, X., Dou, Q. L., Zhang, W. W., \& Cheng, AS (2020). The prevalence and influencing factors in anxiety in medical workers fighting COVID-19 in China: A cross-sectional survey. Epidemiology \& Infection:1-17. doi: 10.1017/S0950268820001107; PMCid:PMC7211492

Lu W, Wang H, Lin Y, Li L (2020). Psychological status of medical workforce during the COVID-19 pandemic: A cross-sectional study. Psychiatry research: 112936. doi: 10.1016/j.psychres.2020.112936; PMid:32276196

Luo, M., Guo, L., Yu, M., \& Wang, H (2020). The Psychological and Mental Impact of Coronavirus Disease 2019 (COVID-19) on Medical Staff and General Public-A Systematic Review and Meta-analysis. Psychiatry Research: 113190. doi: 0.1016/j.psychres.2020.113190; PMid:32544708

Morin, C. M., Belleville, G., Bélanger, L., \& Ivers, H (2011). The Insomnia Severity Index: psychometric indicators to detect insomnia cases and evaluate treatment response. Sleep; 34(5):601-8. doi: 10.1093/sleep/34.5.601; PMid:21532953

NOS (2020). Nepal Ophthalmic Society COVID 19 Ophthalmology Practice Guidelines. Available at: http://www. nos.com.np/covid-19/nos-covid-19-practice-guidelines.pdf.

Pappa, S., Ntella, V., Giannakas, T., Giannakoulis, V. G., Papoutsi, E., \& Katsaounou P (2020). Prevalence of depression, anxiety, and insomnia among healthcare workers during the COVID-19 pandemic: A systematic review and meta-analysis. Brain, behavior, and immunity. doi: 10.1016/j.bbi.2020.05.026; PMid:32437915

Qi, J., Xu, J., Li, B.Z., Huang, J.S., Yang, Y., Zhang, Z.T., Yao, D.A., Liu, Q.H., Jia, M., Gong, D.K. and Ni, X.H (2020). The evaluation of sleep disturbances for Chinese frontline medical workers under the outbreak of COVID-19. Sleep Medicine. doi: 10.1101/2020.03.06.20031278

Risal A, Manandhar K, Linde M, et al. (2016). Anxiety and depression in Nepal: prevalence, comorbidity and associations. BMC psychiatry;16:102. doi: 10.1186/s12888-016-0810-0; PMid:27075664

Shechter, A., Diaz, F., Moise, N., Anstey, D.E., Ye, S., Agarwal, S., Birk, J.L., Brodie, D., Cannone, D.E., Chang, B. and Claassen J (2020). Psychological distress, coping behaviors, and preferences for support among New York healthcare workers during the COVID-19 pandemic. General hospital psychiatry. doi: 10.1016/j.genhosppsych.2020.06.007; PMid:32590254

Tan, B.Y., Chew, N.W., Lee, G.K., Jing, M., Goh, Y., Yeo, L.L., Zhang, K., Chin, H.K., Ahmad, A., Khan, F.A. and Shanmugam, GN (2020). Psychological impact of the COVID-19 pandemic on health care workers in Singapore. Annals of Internal Medicine. doi: 10.7326/M20-1083; PMid:32251513 
Tu Z-h, He J-w, Zhou N (2020). Sleep quality and mood symptoms in conscripted frontline nurse in Wuhan, China during COVID-19 outbreak: A cross-sectional study. Medicine:99. doi: 10.1097/MD.0000000000020769; PMid:32590755

Van Doremalen, N., Bushmaker, T., Morris, D.H., Holbrook, M.G., Gamble, A., Williamson, B.N., Tamin, A., Harcourt, J.L., Thornburg, N.J., Gerber, S.I. and Lloyd-Smith, JO (2020). Aerosol and surface stability of SARSCoV-2 as compared with SARS-CoV-1. New England Journal of Medicine;382:1564-7. doi: 10.1056/NEJMc2004973; PMid:32182409

WHO (2020). Mental health and psychosocial considerations during the COVID-19 outbreak. World Health Organization.

WHO (2020). Naming the coronavirus disease (COVID-19) and the virus that causes it. 2020. URL: https://www. who.int/emergencies/diseases/novel-coronavirus-2019/technical-guidance/naming-the-coronavirus-disease-(covid2019)-and-the-virus-that-causes-it.

Zhang, C., Yang, L., Liu, S., Ma, S., Wang, Y., Cai, Z., Du, H., Li, R., Kang, L., Su, M. and Zhang, J (2020). Survey of insomnia and related social psychological factors among medical staff involved in the 2019 novel coronavirus disease outbreak. Frontiers in Psychiatry;11: 306. doi: 10.3389/fpsyt.2020.00306; PMid:32346373

Zhang WR, Wang K, Yin L, Zhao WF, Xue Q, Peng M, Min BQ, Tian Q, Leng, HX, Du JL and Chang H (2020). Mental health and psychosocial problems of medical health workers during the COVID-19 epidemic in China. Psychotherapy and psychosomatics;89:242-50. doi: 10.1159/000507639; PMid:32272480

Zhou, Y., Yang, Y., Shi, T., Song, Y., Zhou, Y., Zhang, Z., Guo, Y., Li, X., Liu, Y., Xu, G. and Cheung, T (2020). Prevalence and Demographic Correlates of Poor Sleep Quality Among Frontline Health Professionals in Liaoning Province, China During the COVID-19 Outbreak. Frontiers in Psychiatry;11:520. doi: 10.3389/fpsyt.2020.00520; PMid:32595534 